Portland State University

PDXScholar

5-15-1986

\title{
The Development of the Self-Concept in the Young Child
}

Doris Mascall

Portland State University

Follow this and additional works at: https://pdxscholar.library.pdx.edu/open_access_etds

Part of the Child Psychology Commons, and the Counselor Education Commons Let us know how access to this document benefits you.

Recommended Citation

Mascall, Doris, "The Development of the Self-Concept in the Young Child" (1986). Dissertations and Theses. Paper 3706.

https://doi.org/10.15760/etd.5590

This Thesis is brought to you for free and open access. It has been accepted for inclusion in Dissertations and Theses by an authorized administrator of PDXScholar. Please contact us if we can make this document more accessible: pdxscholar@pdx.edu. 
AN ABSTRACT OF THE THESIS OF Doris Mascall for the Master of Science in Counselor Education presented May 15, 1986.

Title: The Development of the Self-concept in the Young Child.

APPROVED BY MEMBERS OF THE THESIS COMMITTEE:

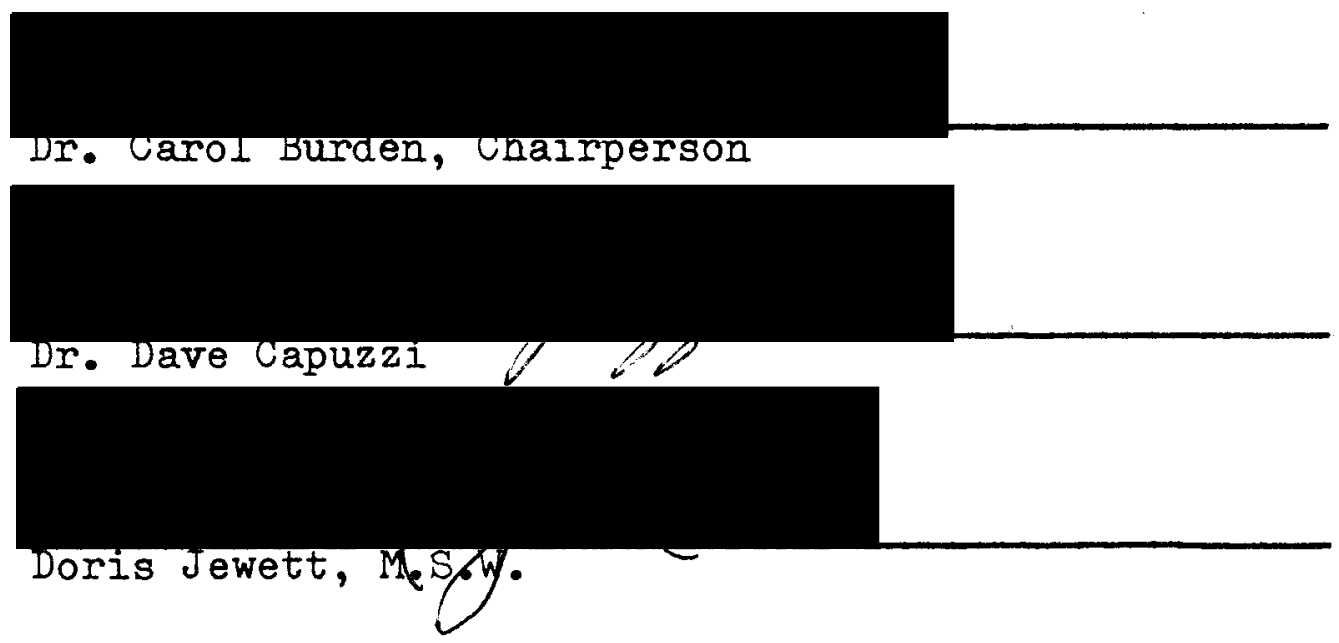

In the first five years of life an evolving experience occurs in the child's mind-body complex which precedes action and influences what the child will do in a given situation. As the child develops cognitively, emotionally, and physically, there is a growing ability to evaluate and anticipate the consequences of behavior before choosing an action. One of the most significant variables that will influence the outcome of the child's evaluative behavior is the child's own concept of self.

The child who has either a negative sense of self or 
is experienceing uncertainty concerning personal worth is more likely to respond inappropriately when life's decisions need to be made. The child who holds a negative sense of self is likely to project this element of uncertainty concerning self onto the environment, thus often eliciting responses that in effect confirm and reinforce this negative view of self.

In contrast, the child who holds a positive view of self, due primarily to the feedback given by significant others, is much more likely to project feelings of competence onto the environment, initiating constructive actions and eliciting positive responses. It is in the early years that the patterns for life are most likely to be established. Though not unchangeable, modifications of these patterns and attitudes towards self are not easily achieved.

The purpose of this thesis is to explore, based upon a literature survey of articles and books published primarily, though not limited to, the past fifteen years, the development of the self-concept in children during the first five years of life. This will include defining self-concept, the establishment of its significance throughout the life span, the role significant others play in the development, an examination of sex-role identity in relationship to self-concept formation, and a critique of available tests and measurements, followed by a conclusion which focuses upon implications for treatment providers. 
Conclusions reached: self-concept is a composite view of self which appears to be a comerstone for decision making throughout one's life span. Significant others, primarily parents, play a major role in the shaping of one's self-concept. Sex-role identity, with one's own sex, is important in the development of a positive self-concept. There is also a need for the development of more adequate tests to measure the self-concept of children five and under. Finally, the research review suggests that intervention may be most successful when parents and child undergo treatment simultaneously. 
THE DEVELOPMENT OF THE SELF-CONCEPT

IN

THE YOUNG CHILD

by

Doris Mascall

A thesis submitted in partial fulfillment of the requirements for the degree of

MASTER OF SCIENCE

in

EDUCATION

Portland State University

1986 
TO THE OFFICE OF GRADUATE STUDIES AND RESEARCH:

The members of the Comittee approve the thesis of Doris Mascall presented May 15, 1986

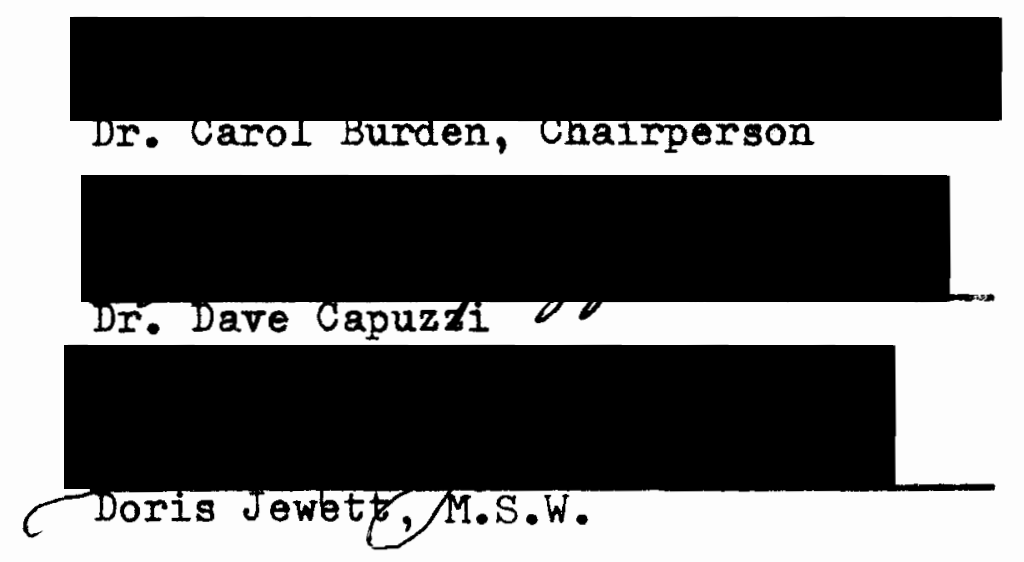

APPROVED:

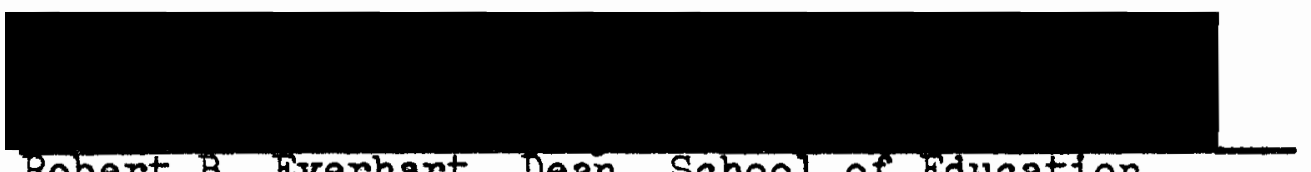

Robert B. Everhart, Dean, School of Education

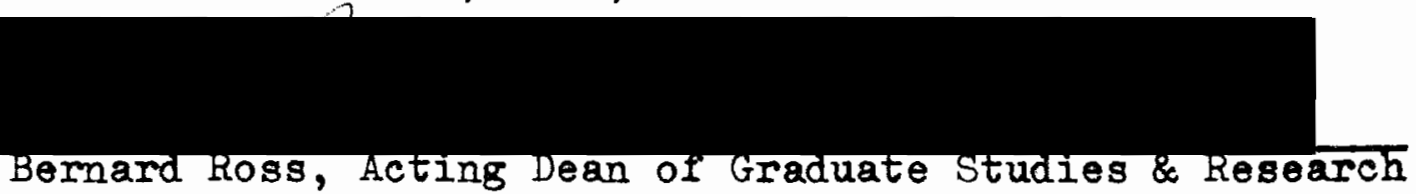




\section{ACKNOWLEDGEMENTS}

I wish to express my appreciation to the committee members, Dr. Carol Burden, Dr. Dave Capuzzi, Doris Jewett, M.S.W. and Dr. David Cressler for the extensive time and energy put into the completion of this project. I also wish to thank my supportive typist and sister, Margaret Schuman, and encouraging husband, David. 
TABLE OF CONTENTS

PAGE

ACKNOWLEDGEMENTS

CHAPTER

I INTRODUCTION . . . . . . . . . . . . 1

Purpose . . . . . . . . . . . . 2

Procedure . . . . . . . . . . . . 2

Limitations . . . . . . . . . . . 3

Definition of Terms ........... 4

II SELF-CONCEPT: DEFINITION AND LIFE SPAN

IMPLICATIONS. . . • . . . • • • . 5

Self-Concept: Definition . . . . . . 5

Implications through the Life Span . . . 8

III THE ROIE OF SIGNIFICANT OTHERS ........ . 13

Prenatal Factors. . . . . . . . . 17

Tre Newborn ............. . 18

The Two's and Three's.......... . 20

The Fourth and Fifth Year . . . . . . . 21

IV SEX-ROIE IDENTIFICATION. ......... . . 33

$\checkmark$ TESTS AND MEASURES ............... 33

The Tests ............... 36

VI CONCLUSION, IMPLICATIONS FOR TREATMENT

PROVIDERS ................. . 42

Conclusion. ................ 42 
PAGE

Implications for Treatment Providers . . . .45

REFERENCES. . . . . . . . . . . . . . . . . . . . 48 


\section{INTRODUCTION}

The self is a phenomenon that has intrigued individuals for centuries. It is believed that st. Augustine (Baldwin 1889) was among the first to study the "self". Since that time, the self has been the object of attention of many researchers. Over the jears, a number of self-prefix terms have been exployed to describe the self, such as self-concept, self-esteem, self-perception, and self-ideation. From among these, it is the self-concept that will be addressed in this paper.

In the first five years of life an evolving experience occurs in the child's mind-body complex which precedes action and influences what the child will do in a given situation. As the child develops cognitively, emotionally, and physically, there is a growing ability to evaluate a situation and anticipate the consequences of behavior before choosing an action. One of the most significant variables that will influence the outcome of the child's evolution is the child's concept of self.

The child who has either a negative sense of self, or is experiencing uncertainty concerning personal worth, is more likely to respond inappropriately to life's decisions. The child who holds a negative view of self is likely to project this element of uncertainty concerning self onto the environment, thus eliciting responses that, in effect, reinforce this negative view of self. 
In contrast, the child who holds a positive view of self is much more likely to project feelings of competence onto the environment, initiating constructive actions and eliciting positive responses. It is in the early years that patterns for life are most likely established. Though not unchangeable, modifications of these patterns or attitudes towards self are not easily achieved.

\section{Purpose}

The purpose of this thesis is to explore the development of the self-concept in children during the first five jears of Iife and to provide a knowledge base for treatment providers to use in designing intervention strategies. The following issues will be explored:

1. The varying definitions of the self-concept;

2. The implications of the self-concept throughout the life span;

3. The role of significant others in the development of the self-concept;

4. The impact of sex-role identity on self-concept fornation;

5. The arailability of appraisal devices for measuring self-concept in the child five and under;

6. The implications for treatment providers.

\section{Procedure}

A literature survey of the development of the self-concept in children, primarily, but not limited to, the past fifteen 
years forms the basis for this thesis. The intent is to explore the early antecedents of the self-concept in children through five years of age, with implications for treatment providers in working with both children and parents. The mafority of the resources are from The Millar Library at Portland State University, Crook County Library, and the writer's personal library.

The thesis consists of six chapters. Chapter I is the introduction. Chapter II defines what is meant by "self-concept," and its implications throughout the life span. Chapter III explores the role significant others play in the development of the self-concept. Chapter IV looks at the relationship of sex-role identity to the self-concept. Chapter $V$ critiques available tests and measures of the self-concept in young children. Chapter VI contains the conclusion with implications for treatment providers.

\section{Iimitations}

- The study is limited to the child five years old and younger.

- The study is limited to the normal functioning child.

- The research is linited to the above listed libraries.

- The study is limited to providing a knowledge base for treatment providers indicating the need for prevention and intervention, rather than establishing a model for implementation. 
Definition of Terms

Self-concept - a composite view of one's self formed through one's experience with one's environment, particularly influenced by significant others (Calhoun and Morse, 1977). Significant others - those persons who are important or who hare sigmificance to the child by reason of the child sensing their ability to reduce insecurity or to intensify it, to increase or decrease helplessness, or to promote or diminish the child's sense of worth (Burns, 1979). Life span - the duration of an individuals life, fron conception to death.

Sex-role identity - an individual's perception of what are appropriate attributes of the individual's sex in today's culture (Burge, 1982).

Treatment providers - psychiatrists, psychologists, therapists, child care workers, counselors, mental health workers, social workers, emplojed in a variety of settings, professionally trained, to bring about growth and development. Interventions - a counseling strateg designed to bring about positive change in the individual and/or system in which the individual is involved. 
SEIF-CONCEPT: DEPINITION AND IIFE SPAN IMPLICATIONS

This chapter determires what is meant by the "self-concept" by exploring the definitions applied by a number of researchers. The inclusiveness of other "self" terms will be examined. The second half of the chapter will explore the life span implications of early self-concept development.

Self-Concept: Definition

Cooley (1956), in the early days of the study of the self-concept, coined the phrase "looking-glass self" to describe the manner in which an individual perceived self through the reflections in the eyes of others. Rogers (1951), also in the early days of the study of self, viewed the self-concept as a composition of the perceptions of one's characteristics and abilities; one's perception of self in relation to others and to the environment; the value one places upon one's experiences and objects; and the goals or ideas which are perceived as being positive or negative by society.

Calhoun and Morse (1977) refer to the self-concept as the manner in which an individual perceives one's self in terms of ability, value, worth, and limitations. They describe the self-concept as the substantive description one employs to identify one's nature, and may also be used by the individual to compare self to others. Soon after a child becomes aware of "self," indicated by the use of expressions 
such as "I," "Me," or "Mine," the child learns what he can and cannot do, as well as internalizing expectations of behavior, imposed by significant others, usually parents. Calhoun and Morse (1977) suggest that the amount and nature of these early interactions and experiences play a significant role in how the individual tends to perceive self. It is postulated that the amount of success encountered during the early developmental period is directly related to the positiveness of the individual's self-concept.

Combs, Soper, and Courson (1963) believe that the self-concept is what an individual believes about self or the totality of one's ways of seeing self. Sears and Sherman (1964) view the self-concept as a synonym of confidence and self-esteem. Mills (1984) describes it in terms of an organized collection of the attitudes and feelings one has concerning self.

Shavelson, Hubner, and Stanton (1976) broadly define self-concept as an individual's self-perceptions which are formed through one's experience with one's environment and are influenced "especially by environmental reinforcers and significant others" (p. 411). Raimy (1971) concurs with this definition by describing self-concept as an organized perceptual set which results from present and past observations concerning self. Simply speaking, it is what one believes about one's self.

Coopersmith, (1967) known for his Self-Esteem InventorJ, writes that this phenomena is a personal judgement of 
worthiness that is expressed in the attitude that an individual holds towexds self. Robeck (1978) describes the self-concept as the private picture an individual carries around defining self; who one is, what one thinks one can do, and how one can best go about it. Ho describes it as being inseparable from self-esteem and self-awareness.

Damon and Hart (1982) express the view that self-concept is basically defined in terms of an evaluative form of self-esteem, again raising the questions as to the differentiation of the "self" terms. It appears that there is no universally accepted difference, and for the purposes of this paper, the terms will remain integrated.

Newman and Newman (1979) define self-concept as, "the result of the cognitive capacities and the dominant motives of the person as they come in contact with the stage related expectations of the culture" (p. 493). Emphasis hero, appears to be placed on the stage related developmental transformations in one's conception of self.

Thus, it appears from the description above that some congruence pertaining to the definition of self-concept can be derived. As defined in Chapter I, it can be seen as a composite view of one's self formed through one's experience with one's environment, particularly influenced by significant others. Significant others, likewise defined in Chapter I, are those persons (Burns, 1979) who are important or who have significance to the child by reason of the child sensing their ability to reduce insecurity or to intensify it, to increase 
or decrease helplessness, or to promote or diminish the child's sense of worth.

Inplications throughout the life span

As indicated, the study of the phenomenon of self has been of interest to many theorists and researchers. William James (1980) looked into cefining the different aspects of self such as the material self, the social self, and the spiritual self.

In one of the first studies researching self-concept, Secourd and Jourard (1953) hypothesized that an Individual's body image is related to feelings about self. They tested this by measuring an individual's degree of satisfaction or dissatisfaction with body parts and processes with a homongm test and Maslows test of psychological security - insecurity. Their findings indicated that "feelings about the body are commensurate with feelings about the self" (p. 347).

Combs and Snygg (1959), also in an early study, theorize that the self-concept is the "cornerstone" for all other thoughts and behaviors. It is the self they see as the "most stable portion of the individual's phenonenal field and it is the point of reference for everything he does" (p. 122). Thus, they assert that the concept of self will determine to a large extent the situations one involves oneself in as well as the thoughts and actions that follow.

The far reaching effects of the self-concept begin early. Benninga (1980), in a recent study describes self-concept as having an immediate effect upon school 
performance. A child with a positive self-concept is generally more optimistic, solf-confident and high achieving. This is in agreement with research done by White (1969) and Bruneua (1984) who conclude that the self-concept is a major determinant of success in the classroom.

Willians' and Cole's (1968) findings indicate that self-concept is related to one's conception of school, social status at school, emotional adjustment, and academic achievement. Research also indicates that there is a positive relationship between a child's self-concept and the manner in wich teachers perceive the child, and the child's school performance (Davidson and Land, 1960; Rosenthal and Jacobson, 1968).

Rosenburg (1979) indicates that there is a shared assumption among psychologists and educators that a child's positive and negative foelings concerning self are factors that have implications relating to the child's secial relations, later school performance and level of mental health. Damon and Hart (1982) state that positive feelings concerning self are significantly related to "successfur adaption to the world in general" (p. 842).

More and more educators and researchers (Soule, Drummond, and McIntire, 1981) are ackowledging that the affective components of learning are complementary to the cognitive components. Thus, concerns for the child's feelings, values, and attitudes are important in successful academic learning. As a result of this growing awareness of both affective and 
cognitive derelopment, interest in the development of the self-concept during these early critical jears has grown (Jensen, 1983).

One's self-concept affects not only school success, but also has a tremendous impact upon career choice and resultant feelings of success or failure, plus competence or incompetence. Wise (1976) writes that the self-concept ties strongly into the "belief held about an ability one has and how successful one would be at an activity involving that ability" (p. 51). Super, (1969) also stresses that one's self-concept has a decided impact upon one's vocational or career choice. He points out that with a positive view of one's self, it is easier to realize one's role in the world of work.

Newman and Newman (1979) describe the self-concept as central to the gradual evolution of an individual's personality. This can be seen in the direct relationship to the degree of satisfaction or tension an individual experiences with regard to individual characteristics, capability, and performance through the life span.

Ellsworth (1967) describes one's self-concept, and the congruence of related feelings as the major cause of many individual's difficulties in life adjustment. He describes negative self-concepts as centering around two areas: the feelings of inability to cope adequately in society, and the feelings of being unlovable. In contrast, a positive self-concept is described in terms of feelings of adequacy, capability in dealing successfully with the world around, 
likability, feeling valuable, and intrinsically free and worthy.

The self-concept also has an impact upon mate selection. In the developmental phase of life where successful attainment of an intimate relationship is the goal (Newman and Newman, 1979), obstacles can arise from "left over" childhood experiences resulting in feelings of inadequacy and unlovableness influencing mate selection. These obstacles can take the form of shame, guilt, feelings of inferiority, alienation or over-dependency in adult life (Erickson, 1963).

In middle adulthood Erickson, (1963), has identified the individual's tasks to be related to productivity and creativity (Newman and Newman, 1979). The impact of the self-concept can be seen during this Iife stage. For instance, the individual who does not have a positive self-concept, characteristically will not feel a sense of accomplishment during middle adulthood and will be unable to perceive self as having adequate resources to make anj worthwhile contributions to society.

Just as the child and young adult with a positive self-concept has a greater likelihood of forming and maintaining positive relationships with other individuals, so does the older adult (Newman and Newman, 1979). Iowenthal and Haven (1975) stress that the maintainance of close peer relationships during the latter phase of life as significantly related to overall positive mental health.

Likewise, just as the child and young adult with a 
positive self-concept appears to be positively engaged in their social environment (Newman and Newman, 1979), so does the older adult. Older adults who are most active are most satisfied with life, while those who are the least active are the least satisfied.

In conclusion, it appears that the development of self-concept is most critical during the first five joars of life (Burns, 1979). Furthermore, it is influential throughout one's life span influencing such factors as school success, positive peer interactions, career selection, intimate relationships, middle adulthood generativity, and later life satisfaction. It is apparent that "something" happens during the early jears that can dramatically set the tone for overall life satisfaction. It is this issue that will be addressed in the next chapter. 


\section{PHE ROLE OF SIGNIFICANT OTHERS}

This chapter looks at the role that significant others, most commonlJ parents, plas in the derelopment of the child's self-concept during the first five jears of life. The mother's influence upon her child potentialls begins at conception. It is after birth that seloctive reinforeing and modeling come into play. The importance of the influence of significant others will now be more carefulls explored.

Butler (1969) emphasizes that bJ age three a child has developed a well integrated view of self. This then becomes the "core and precipitator" of the child's future behavior. As Butler observes:

Iife is not over at age three, but the general view toward the world and towards one's self is already present. Possibilities for change are always present, but the longer a behavior persists the more difficult it is to change.

WJile (1961, 1979), in theorizing about parental influence, asserts that it is a generally accepted premise in psjchological literature that significant others, particularls parents, play a primary role in the development of the child's self-concept. Parents plas both the role of a model and a source of reinforcement that both shape and mold the child's Ideas and feelings concerning what kind of person the child is and would like to be. This begins with the infant's total dependence upon the parents. This places the parents in the unique position of being able to reinforce selectively the child's learning, and as WJlie indicates, influenceg the 
child's general perceptions of self, the development of standards of conduct the child holds as goals, and self-acceptance including both negative feelings and linitations.

Both Rogers (1951) and Wylie (1961, 1979) speak of a child's self-concept as greatly influenced by the self-concepts of the parents. A parent who tends to be self-rejecting, minimizing or negating of their own strengths while emphasizing weakeseses, tends to be unable to give adequate love and is incapable of providing an adequate model of self-acceptance.

Wrlie (1961, 1979) also speaks of some limited research indicating that the manner in which the child perceives self is associated with the parents' reported level of regard for the child. This appears somewhat cjelical in that parental interest and rapport are associated with the child's perceived positive self-concept.

Kohut (1971) describes the process in which the child learns to perceive self as determined primarily through interaction with "self-objects". These are defined as people, initially parents, whom the child experiences as part of self. Kohut identifies the first major task of the parents in the self-object role as mirroring to the child approval and confirmation, thus providing a basis for self-acceptance and value. The second task is idealization in which the parents allow themselves to be seen as powerful and ideal bJ the child, thus providing a positive model.

Many other researchers stress the importance of 
significant others in the development of the self-concept during the early Jears (Elrod and Crase, 1980; Branden, 1969; Stringer, 1971). Specific parental behaviors identified as being significantls related to the child's self-concept are acceptance by mothers (Coopersmith, 1967), warmth (Sears, 1970), interest and concern (Coopersmith, 1967; Rosenburg, 1963), limit setting (Coopersmith, 1967), companionship (MacDonald, 1973) and democratic child rearing practices. A study done by Samuels and Griffore (1978) indicates that there is a significent correlation between mothers who experience high anxiety and a child who has a negative self-concept. There also appears to be supportive data (Coopersmith, 1967) indicating that conflict and tension between parents is associated with a negative self-concept in a child. A child who reports a high incidence of parental or family conflict is more likely to have a negative self-concept even if the conflict occurred several years prior (Raschke and Raschke, 1979).

Cooper, Holman, and Braithwaite (1983) concur with these findings. In their study they found that family cohesion "when measured through one child's perceptions of family relationships, has an important influence on the development of self-concept" (p. 157). They assert that a negative self-concept can be expected from a child who perceives conflict between parents or between self and one or both parents. Raschke and Raschke (1979) indicate that perceived parental happiness is positively correlated with 
a child's self-concept. This holds true for both intact as well as single-parent or other family structures. Therofore, regardless of family structure, the greater the perceived happiness of the parents, the more positive the child's self-concept.

Burns (1979) likewise states that many personality theorists and researchers agree upon the role that significant others play in being primary sources of information concerning self. The impact that significant others play in the child's acquiring a concept of self can be understood with the realization that few things are more relevant to the child than others' reactions to behavior, appearance and simply the child's presence.

Burns (1979) establishes the parents as having the greatest impact in the developing conception of self due to their position of authority and source of trust. The self-portrait is gradually modified and reworked according to the experiences the child has and the way in which the child perceives others as reacting to self. Burns describes the process as one in which the child becomes "less and less a perceptual object and more and more a conceptual trait" (p. 162).

Sngggs and Combs in an early study (1949; cited in Burms, 1979) emphasize the importance of the evaluation of significant others on one's self-concept:

As he is loved or rejected, praised or punished, fails or is able to compete, he comes gradually to regard himself as important, adequate or inadequate, 
handsome or ugly, honest or dishonest . - or even to describe himself in terms of those who surround him ... (p. 831)

The first five years of life (Burns, 1979) are seon as the ones in which the basic framework of the personality and self-conceptions are established. During this early developmental period, the child is valnerable. There is a high degree of physical, social, and enotional dependence upon significart others with whom the child participates in intimate and intense daily interactions.

These first human interactions are described by Erickson (1963) as setting the stage for what can be expected in later life. The manner in which the child is handled initially, 28 significant others satisfy or fail to satisfy the needs for love, food, confort and security, has unrenitting influence upon the development of self. The child learns quickly that the world is safe and to be trusted, or hostile. Sensitive, loving care enables the child to develop a basic sense of security and trust, particularly during the first jear of life. The developmental phase between the ages of 2 and 5 seen critical for establishing a workable balance between dependence and autonony.

\section{Prenatal factors}

Sone experts in the field believe that the influence of the child's mother begins in the prenatal stage. Though this is a relatively new field, some studies, such as Hurlock (1968) and Ferguson (1970) suggest that emotional stress as well as documented chemical stress experienced by the pregnant 
mother potentially can alter the movements of the fetus from normal to hyperactive. Hence, fetal hyperactivity in the latter months of the pregnancy appears to be related to feeding difficulties, failure to gain weight, sleep problems, general irritability, distractability, and other conditions leading to a difficult postnatal life adjustment.

Questions have been raised as to the psychological development of the unwanted fetus (Yanamoto, 1972). Can a mother who professes rejection of a pregnancy later adjust to the birth without adverse consequences to the child? How often and how long does the rejection continue into the child's early jears of life? How critical are the initial first few months to the later personality adjustment of the child; speciffcally to the development of the child's self-concept? These questions as of jet appear to be unanswered.

The Newborn

Burns (1979) describes the newborn as having no self-awareness, because all behaviors are dominated by the need to satisfy bodily disconforts. "Wherefore, the earliest messages concerning how people feel about the infant iie in the reduction of physiological needs" (p. 161). As the infant is being fed, bathed and changed, the message of boing valued and accepted is commicated. The accompanjing caresses, smiles and vocal intonations come to be associated with being cared for. Burns writes that through this, the infant learns to seek out the feeling of being valued by others, as it is initially associated with the satisfying of 
physiological needs.

It is apparent that the newborn is completely dependent upon others for survival. The satisfaction of the infant's biological needs greatly influence feelings of security (Yamamoto, 1972). A phenomenon of "bi-directionality" appears to occur between the infant and significant others. Kagan (1968) describes the interaction as a "ballet in which each partner responds to the steps of the other" (p. 80). Therefore, the mother's actions tend to mold the infant's behavior, as well as the infant having an impact upon the mother's reactions. A mother is more likely to attend a crying infant than a quiet one, just as an infant who smiles is likely to elicit a similar response from the infant's mother. Thus, the development of the self-concept, either negative or positive is perpetuated by this interactive dimension.

From the very beginning of the infant's life, Yamamoto (1972) discusses the fact that certain behaviors will be selectively reinforced, while others will be selectively weakened. It is in the initial firgt weeks that the foundation for later interaction between the infant and significant others is established. During this time, the significant others begin to recognize and adapt to the infant's individual reaction patterns and requirements (Ferguson, 1970). It is believed that the quality of "individualized adaption" to the infant's needs is critical in the development of "trust vs. mistrust" (Erickson, 1963), 
which forms the foundation for a positive self-concept.

From the very beginning, it appears that a mother's attitude towards her infant may significantly influence the manner in which the child later preceives self, thus leading to psychological wellness or emotional difficulties. Broussard and Hartner (1970) conducted a longitudinal study in which one hundred and twenty full term firstborn infants were categorized at one month of age into a high-risk or low-risk group for the potential development of later emotional problems. The basis of predictions were measurements of the mother's perception of her infant as compared to what she felt was average for infants at that age. When the children were $41 / 2$ they were evaluated for emotional disturbance by two child pgychiatrists who had no knowledge of the predicted risk rating. The association between prediction by the mother and outcome of emotional disturbance was statistically significant. Thus, it appears that as early as one month of age, a mother's attitude towards her infant potentially influences the infant's later well being.

The Two's and Three's

It is during this stage of life that another phenomenon is occurring (Peairs and Peairs, 1974), that of self-assertion and exploration. As Sandler (1968) indicates:

A child who is able to explore his environment freely and fairly aggressively, without diminishing his sources of basic safety feelings, may retain this freedom to explore (in activity or thought) throughout his life because he has found appropriate techniques for doing this... (p. 291) 
Erickson (1963) describes the primary task during this stage of life as the establishment of autonony. It is critical that the child begin to experience self as $a$ "successful agent." The child seems to vacillate here between hanging on and letting go. It is imperative that significant others give the child permission for both.

The Fourth and Fifth Yes:

As the child enters the fourth and fifth jear, different developmental phenomena are occurring. The child is learning to entertain self. There is commonly an attechment established with caretakers outside of the family, along with a developing awareness and practice of the standards the family promotes (Kagan, 1984). The child is becoming much more in control of behavior, linguistically sophisticated, motorically coordinated, and able to anticipate wishes and actions of others.

An expanding range of experiences are necessary for the continued development of a positive self-concept. Parents can provide skills which will result in greater feelings of success in entering school, such as preliminary knowledge of letters and numbers and encouragement to persist when faced with challenging problems. Along with providing skill building opportunities, parents are most importantly role models with whom the child identifies (Wylie, 1961, 1979; Kagan, 1984). The child who perceives the parent as nurturant, just, and virtuous, and identifies with them, will come to regard the self as possessing these desirable qualities. 
As in the earlier stages, the child needs to continue to believe that they are valued by the signtficant others in their Iife (Kagan, 1984; Dobson, 1979; and Briggs, 1975). This valuing is undermined when the child perceives that they are failing to meet parental standards. It is Kagan's belief (1984) that eren at the approach of the second birthday, the child demonstrates behavioral signs of anxiety if unable to implement a behavior that the child feels obligated to display. The child is unable to ignore the standards due to the physical and emotional dependency upon others. The child is likely to incorporate the standards as one's own, and if unable to meet them, will perceive self as inadequate. The resulting feeling may be inadequacy to cope with problems encountered in everyday life and an unealthy desire to gain the approval and affection of significant others, even to the extent of self-destructive behaviors. Mills (1984) states it simply: "The greater the amount of success children experience during their early developmental period, the better their self-concept" (p. 178). The criticalness of significant others is once again established. 


\section{SEX-ROTE IDEATIFICATION}

Yamamoto (1972) describes the establishment of one's sex-role identification as another facet of the basic foundation in the development of one's self-concept. Burge (1982) describes sex-role identity, defined as an individual's perception of what are appropriate attributes of the individual's sex in the culture they are living, as one of the most salient of the social roles. It is also described as the "most pervasive aspect" (p. 249) of an individual's self-concept because it directs the majority of overt behavior, omotional reactions, cognitive functioning, covert attitudes, as well as general poychological and social adjustaent (Mussen, 1969; Sears, 1965). Thus, it is apparent that an individual's perception of their sex-role influences self-concept (Block, 1973). The following chapter will include a literature review addressing the development of traditional sex-role identification and traditional sex-role stereotyping.

As with the formation of the entire concept of self, sex-role identification begins very early in life. Results of a study by Kuhn, Nash, and Brucken (1978) indicate that a child as joung as 2 jears of age possesses substantial knowledge of sex-role stereotypes.

Iowis (1979) speaks of ways sex-role behavior is deternined: biologically, by the effect of the hormones; alternatively, by the shaping effect of the social 
environment; or by a combination of the two. In speaking of the child's dereloping sex-role, he points out that understanding and knowledge come through the child's interaction with others. Maccoby and Jacklin (1974) speak of sex-role orientation as occuring through (pp 1. - 2.):

1. Initation...

2. Praise or discouragement . .

3. Self-socialization: the child firgt develops a concept of what it is to be male or female, and then, once he has a clear understanding of his own sex identity, he attempts to add his own behavior to his concept of what behavior is sex-appropriate. of course the third process calls upon the other two. A child's conception of what is sppropriate behavior for a male or female will depend both upon what he sees males and females doing and upon the approval or disapproval that these actions elicit differentially from others. Both of these kinds of events constitute information the child can draw upon in building his concept of sex-appropriate behavior.

Wylie, (1961, 1979) speaks to the initative importance of the child and the same sex parent. Her findings indicate that sex identification factors were evident in cases where a child with a positive self-concept when compared with a child with a negative self-concept, perceived their own self-concept as being more congruent with the self-concept of the parent of the same sex. Samuels and Giffore (1978) concur with this in stating that identification with the parent of the same sex has the greatest impact upon the development of the child.

Newran and Newman (1979) speak of the importance of the child's identification with the parent of the same sex. They state that it is through this process that the child comes to emulate the parent of the same sex thus initiating the 
intermalization of the parent's values, attitudes and view of the world in general.

The motivation as to why a child strives for identification has been studied. Psychoanaljtic theory (Newman and Newnan, 1979) stresses fear of loss of love as the process involved. This may be founded upon the child's initial dependeney upon the parent. Therefore, the child behaves like the parent in order to ensure a continued positive relationship. Eventually the child incorporates aspects of the loved one's personality into their own self-concept as an attempt to achieve independence. "If children can be like their loved parent, they do not require the parent's continuous presence in order to reassure themselves about that loven (p. 176).

Eaton (1983) sheds some light upon gender understanding and sex-role stereotyping based upon the developmental stage the child is believed to be passing through (Thompson, 1975). The three steps of gender awareness that should be attained by the child are: labeling, stability, and constancy.

In the first phase, the child learns to correctly label their own and others' gender (Eaton, 1983). Here a child, when shown a picture of another individual, can generally classify the individual correctly by gender. It is Thompson's belief (1975) that virtualy all three year olds and most two year olds have attained this level of gender awareness.

In the stability phase, the child recognizes that gender is a permanent attribute of individuals (Eaton, 1983). The 
child who has attained this step can correctly answer questions such as, "When jou were a baby were you a little boj or a little girl?" or "Could you be a (opposite sex) tonorrow?" It is believed that the majority of four year olds have attained this stage (Eaton and Von Bargen, 1981; Slaby and Frey, 1975).

The third and most advanced stage of gender understanding is constancy and requires "the recognition that gender is constant and invariant despite possible changes in activity, dres8, or appearance" (Eaton, 1983, p. 30). Questions such as "If jou played with (opposite sex children) and did (opposite-sex) things like this (shown picture of stereotypic opposite-sex toy, what would you be - a boy or a girl?" or "Suppose a child like that one (pointing to a pictured boy) lets their hair grow very long; is it a girl or a boy?" (p. 30 ). To be in this stage a child must understand that gender is based upon genitalia and not on clothes, hair style, or behavior preferences. Studies indicate that very few pre-schoolers have attained this stage (Eaton and Von Bargen, 1981). The average age of attainment is between seven and nine jears.

The typical three to five jear old, then believes that gender is a generally stable personality characteristic, but that it also is an attribute that can be changed by cross-sex activities, hair styles and elothes. It follows then that the child (Eaton, 1983) in the stability stage will take gender more seriously as an organizer of experience tending 
to exemplify itsels in sex-role stereotyping behavior. "If one believes that gender, though generally stable, can change if cross-sex behaviors are engaged in, one maj quite reasonably aroid such activities" (p. 33). Once constancy is attained, cross-sex activities are potentially less threatening to the child because engagement in them would not jeopardize one's basic sexual identity.

The basic understanding of sex role differentiation is learned early (Eaton, 1983: Thompson, 1975; Eaton and Von Bargen, 1981; Slaby and Frey, 1975; Kuhn, Nash and Bruchen, 1978). From the perspective of these current researchers, and others such as Elrod and Crase (1980), Hall and Halberstadt (1980), Burger (1982), and Bell, Menke, and Ianke, (1980), the relationship between gender and self-concept will be explored.

Current research seems to indicate that overall, boys are found to have more positive self-concepts than girls. Elrod and Crase (1980) found this to be the case in a study of four and five jear olds. They conclude that males are perceived as having more desirable characteristics and are thus more valued than females in our society. Hall and Halberstadt (1980) as a result of a longitudinal study postulate that boys and girls are becoming more masculine over time. They suggest that girls are beconing less feminine and passive as a result of their growing awareness of the perceived negative aspects of femininity as communicated by those around them. 
In researeh done by Burge (1982), findings also indicate that strong male sex-role identity is related to a positive self-concept. These findings concur with studies done by Berzins, Welling, and Weiter (1978); Zalk and Katz (1978), and Ginsberg and Miller (1982). A boy who identified with the male sex-role felt better about himself. Other findings in her study could possibly have interesting ramifications in today's society. Children in her sample who made polarized, sex-typed choices, as part of the study had more positive self-concepts than did children who made non-polarized choices. Perhaps, this indicates that a child who knows an appropriate role feels good about self, while confusion concerning one's sex-role way result in a negative self-concept. A degree of sex-role idontification appears to be critical. It must be kept in mind that a rigid adherence to traits only associated in the past with one sex is severly liniting. Perhaps a balance is in order.

In a study done by Bell, Manke, and Lamke (1980) of sex-role traits in pre-schoolers, findings indicate that a positive self-concept was strongly related to masculinity, while the relationship between a positive self-concept and femininity was not significantly related. These findings concur with the previously mentioned studies that the self-concept/masculinity relationship is underway in the preschool jears. It is also interesting to note in this study that the children rated as having a positive self-concept were those who were perceived as assertive, active, and 
athletic, stereotypically traits associated with masculinity. Thus, the studies relating self-concept with gender identity or sex-role, in general, indicate males have a more positive self-concept than females even during the initial years. Sex-role stereotypes, indicating masculine traits as superior are already in operation as early as two. Kuhn, Nash, and Bruben's (1978) however, found sonewhat different results in their study. Concerning sex-role concepts of two and three year olds, they found that girls at this age were ascribing predoninantly negative characteristics to little boys. This is apparently reversed by adulthood. Boys at this age tended to demongtrate concepts of ralued "male only" future roles such as governor, doctor, pilot, which were not shared by girls. Why the difference? The authors postulate that perhaps there may be different courses of development pertaining to the attainment of sex-role stereotypes in the different sexes. This raises questions to be addressed by further research.

Just as significant others, particularlj parents, play a major role th the shaping of a child's self-concept, their influence in sex-role identification can be seen. In Elrod and Crase's study (1980), differences in parental treatment towards four and five year old sons and daughters were explored in relationship to the child's self-concept. Results indicate (Elrod and Crase, 1980) that parents behave differently towerds different sexed children. Fathers tend to interact more with sons than with daughters. Mothers interact more 
with daughters than do fathers, but also interact more with sons than fathers. The mother's interaction tends to be more similar towards sons and daughters then is the father's interaction. Results also indicate that mother's behavior has a far greater impact on male or female children than does the father.

In a closer look at specific behaviors (Elrod and Crase, 1980), it appears that a positive self-concept in a daughter is related to "the mother's communication that she values the child through actions and deeds" (p. 726). Behaviors in a father that appear to be related to a negative self-concept in a son, involves limit setting and immediacy of assistance.

It also appears from these results that boys and girls may react differently to the action of their parents even when parents (Elrod and Crase, 1980) report actions in similar manners towards both boys and girls. Thus, there may be reason to believe that one must take into consideration the sex of the child when looking for specific behaviors which relate to a positive self-concept, while giving careful consideration to non-perpetuation of sex-role stereotypes.

From Elrod's and Crase's study (1980), it appears that mothers have the most interaction with both children, thus potentially having the greatest influence on them. Schwartz (1982) examined the relationship between stated and unstated goals mothers maintained for the pre-school child and explored the effects of these attitudes upon the child's 
self-concept, dependency level and sex-role stereotyping. Results from the study indicate that there were no differences between stated goals for sons and daughters. However, unstated attitudes and behaviors do appear to contribute significantly to the prediction of stated goals, thus suggesting there may be incongruence between what mothers' state they want and internalized attitudes.

For both boys and girls (Schwartz, 1982) stated, high maternal expectations and a nontraditional sex-role orientation contributed to the prediction of low levels of dependency, while traditional sex-role orientation contributed to high dependency prediction in girls. Nontraditional sex-role orientation appeared to contribute significantly to a positive self-concept. Schwartz concludes that although mothers express similar goals for all children, their sex-role orientations may significantly affect the dependency level and self-concept of their daughters.

Burger's findings (1980) indicate that a child's self-concept appears to have a systematic relationship with age, caretaker, and sex-role identity scores. The older the child, and the more traditionally sex-tjped, the more positive the self-concept. It's also interesting to note that Burger's findings indicate that the child whose father was the major caretaker had the lowest self-concept. The child with both parents serving in that role came next. The child whose mother was major caretaker was next. The child with the highest self-concept had someone other than parents 
as major caretakers. Though lacking concurrence of other studies, this has interesting ramifications. A possible interpretation could be that a wider circlo of positive caretakers brings about a more positive self-concept. Another potential implication could be the child's constraints of bonding with parents verses greater affective Ireedom felt with other less evaluative caretakere. 


\section{TESTS AND MEASURES}

This chapter will examine research concerming available tests and measures of the self-concept in children five and younger. It is evident that adequate instruments for this population need to be dereloped.

Self-concept research appears to have taken an interesting course. Damon and Hart (1982) speak of the study of self-concept as usually meaning the study of an "evaluative orientation to the self called 'self-esteem'" (p. 841). This appears to be true of the majority of studies explored by Wylie (1961, 1979) in her thorough review of the self-concept.

According to Damon and Hart (1982):

Self-esteem is affective orientation and can be assessed according to its positive or negative valence. That is, measures of esteem determine the extent to which a subject positively or negatively values an object. The assessed variable therefore is the subject's affective orientation toward an object; once the positive or negative direction of the subject's orientation has been established, the measurement, indexes are essentiallJ quantitative. (p. 842)

Damon and Hart (1982) raise the question as to why the study of self-concept is approached through an affective and quantitative dimension such as self-esteem rather than through a more cognitive framework such as understanding. The answer is believed to be found in the shared belief bJ some professionals that a child's negative and positive feelings concerning self play a major role in the child's 
social relations, school performance, mental health, and "successful adaption to the world in general" (p. 842). This belief has encouraged test makers to design measurements of feelings as indicators of self-concept. Wylie (1961, 1979) writes that "theory and conventional wisdom very confidently predict strong trend" (p. 690) for the connection between the feelings a child holds toward self and successful adaption to life." She believes that the problew lies in the methological inadequacies inherent in existing scales measuring self-concept. These have interfered, according to Wylie, with what should be a straight forward attempt to establish empirical relationships between one's self-concept and other critical life variables.

White and Human (1976), Jensen (1980), write in concurrence with WJlie (1961, 1979) and Damon and Hart (1982) that problems exist in the measurement of one's self-concept. This is particularly true for pre-school age children, because of limited or nonexistant reading skills (White and Human, 1976). Jensen (1983) states that the "assessment of pre-school self-concept has often proved difficult, and few adequate instruments have been developed" (p. 89). It seems apparent that improved measures of early self-concept are greatly needed.

There are some researchers who still question the measurement of self-concept itself. Gergen (1971) states: 
"Clearly, we cannot measure it directly as there is no direct access to another's private experience. The most we can do is to infer the nature of a particular experience from various overt behavioral indicators" (p. 16). Piers and Harris (1964) state that "validation of self-report scales is always difficult, since the appropriateness of behavior and other criteria outside the self can be questioned" (p. 94).

As is indicated, an overview of the research regarding self-concept (McCandles and Evans, 1973; Henderson and Abrams, 1983) indicates that there is a lack of agreement among professionals in the field as to what approved methods for evaluation may be. A further complication can be found in that manj researchers come up with their own measures, complete with unique theoretical definitions and methodologies to measure the construct. Consequently, the "results of much research are not comparable and sometimes ambiguous and contradictory" (Henderson and Abrams, 1983, p. 2). It would appear now that the primary task of self-concept theorists would be to define more precisely self-concept.

As indicated there are few studies which focus on the self-concept of the child five and younger. The majority are focused on older children, often utilizing school performance as a sub-construct. There are apparent complications in attempting to measure the self-concept, particularly for the joung child. There are however, 
some measurements available. It is in the exploration of these resources to which the remainder of the chapter will be devoted.

\section{The Tests}

Henderson and Abrams (1983) conducted a study in which they investigated three self-concept tests, the Thomas Self-Concept Values Test, the Pre-School Self-Concept Picture Test and the Purdue Self-Concept Scale for Pre-school Children. Four selected dimensions of the self-concept, physical skill, phjsical appearance, intelligence and cooperation, were studied in relationship to the tests. These somewhat different aspects of self-concept were selected by a group of treatment providers rating a list of perceived self-concept attributes according to their professional experience with children.

The following description is given for the Thomas Self-Concept Values Test (Henderson and Abrams, 1983):

The Thomas Self-Concept Values Test is an individually administered instrument which provides a psychological technique for assessing the personal self-concept values of pre-school children. The test was designed to allow the child to reflect and report on himself/herself as subject and object in eight of 14 commonly conceived value dimensions. The questions regarding the self-value factors are asked of the child in reference to how he perceives himself, how the child's mother perceives him, how the child's teacher perceives him, and how the child's peers perceive him. (p. 5)

The Thomas Self-Concept Values Test were also used by Landry, Schilson, and Pardew (1974) in a study in which the effects of a pre-school self-concept enhancement program 
on a group of four year old children were investigated. They describe the process of the testing a bit more completely. "The child is first photographed to insure greater objectivity of response". (p. 424). The child is then asked to refer to the picture of self while responding to fourteen orally presented alternate-choice stimuli (e.g., Is (child's name) happy or sad?) "The fourteen self-value stimuli are described as value dimensions of social experience: happiness, physical size, sociability, ability, sharing, male acceptance, fear of things, fear of people, strength, cleanliness, health, attractiveness, material possessions, and independence." (Thomas, 1969; as cited in Landry, Schilson, and Pardew, 1974, p. 423).

The fourteen scale items (Landry, Schilson, and Pardew, 1974) are seen as related to the developmental tasks and problems which four-to-six-year-olds experience. The Thomas Self-Concept Values Test jields fourteen self-value scores and four self-concept referent scores as based on how the child perceives self as described in the research done by Henderson and Abrams, (1983). Thomas reports (1969; as cited in Irandry, Schilson, and Pardew, 1974) that test retest reliabilities for the nineteen scores range from . 34 , on the health value score, to .93 , on the sharing value scale. The average test-retest reliabilities for the sub-scale is reported to be .75 and .78 for the overall self-concept.

Henderson and Abrams' (1983) second measure of the self-concept was the Pre-School Self-Concept Picture Test. 
This a nonverbal picture test which assesses self and one's ideal self-concept. The test as Henderson and Abrans describe it, consists of ten plates with painted pictures on each plate. The characteristics pictured represent ten negative and ten positive characteristics. For seven plates, the positive and negative characteristics are identical for both sexes. On three of the plates sex differences are noted. They give no information regarding reliability.

The third test used by Henderson and Abrams (1983) was the Purdue Self-Concept Scale for Pre-school Children. It is a nonverbal picture test intended for individual administration. It is described as being developed to assess the evaluative component of self-concept in the pre-school child, age 3,4 and 5. (p. 72). It is a noncomercial instrument intended for research use and evaluation studies, only. It "is not intended for individual diagmosis of children." (p. 6).

Burge, (1982), who also used this test in her research exploring the relationship between sex-role identity and the child's self-concept describes it more fully. Dereloped in 1974 by Cicirelli, it consists of a booklet of 40 items, each consisting of two cartoon pictures, one depicting a positive self-description and the other depicting a negative self-description. The subject is asked to identify which picture is most like themselves. Cronbach's coefficient alpha index of reliability for this scale is .86 (Cicirelli, 1974; as cited 
in Burge, 1982).

Henderson and Abrams (1983) drew the conclusion from their study that these three self-concept testa do not accurately measure the following four. selected dimensions of self-concept: physical skill, physical appearance, intelligence, and cooperation. Caution is given to those who might attempt to assess a child's self-concept with these measures.

It must be kept in mind that the conclusions reached by Henderson and Abrams (1983) indicate that these tests do not accurately measure their four selected dimensions of the self-concept. The possibility exists that the four dimensions may not be significant enough to be predictors of a child's self-concept. The necessity for adequate testing measures to obtain a more "accurate or complete profile" (p. 10) is apparent.

Two other self-concept measures for young children seem to be currently used in today's research. The first is the I Peel . . Me Peel Self-Concept Appraisal (Benninga, 1980). This is a 40 - item inventory developed by Yeatts and Bently (1968) to assess self-concept in children ages 5- 8 (White and Human, 1976). Although Indicated primarily for the school-age child, it has been used, satisfactorily with 3-, 4-, and 5-Jear olds.

It is designed to measure five dimensions of the self-concept: "General Adequacy, Peor, Teacher-School, Academic, and Physical" (White and Human, 1976, p. 192). 
The 40 items picture various situations such as interaction among peers and adults as well as building-creating scenes. Benninga (1980) states that:

The items were drawn from the spontaneous verbal expressions of children. Tape recorders were placed in bathrooms, libraries, classrooms, conversation corners, and in the free playrooms. Pictorial representations of the concerns expressed by the children were made and validated by an independent cross-section of socioeconomic, geographic, and ethnic groups. (p. 28)

Each item is a silhouetted picture of some event related to the child's life experience (White and Human, 1976). "At the bottom of each item are five faces which graphically represent very sad, a little sad, not sad - not happy, a little happy, and very happy" (p. 192). The child places an " $X$ " on the picture of the face that indicates the child's feelings. The coefficient for reliability was not stated by the researchers using this measure.

The Piers Pre-school Pictorial Self-Concept Scale (1983) is also a measure of the young child's self-concept seen in the literature. The Piers Scale, developed in the early 1980 's, is a "30-item self-report inventory with separate but identical versions for bojs and girls" (Jensen, 1983, p. 90). Each item consists of two pictures in which the child is asked to indicate the one more closely describing self. The predicted reliability and validity were unstated in this research.

Jensen (1983) used this instrument in looking at the 
relationship between self-concept and age, family structure, and gender in children three to six yearg old. She favorably describes the use of this instrument: "The Piers Pre-school Pictorial Self-Concept Scale is a worthwhile measure for research and development" (p. 62). She stresses that more data is needed concerning the validity of the scale: " . . comparisons with other instruments, observed behavior, and other subject variables" (p. 62) are necessary.

High reliability and validity are not indicated for the five current measurements of self-concept of the young child reviewed in the literature. Therefore they should not be used independently by treatment providers for assessment purposes. However, the use of these measures as techniques assisting the treatment provider in identifying areas of concern for the child may prove worthwhile. 
CONCLUS ION :

IMPLICATIONS FOR TREATMENT PROVIDERS

Conclusion

The purpose of this thesis was to explore the development of the self-concept in the child during the first five jears of life, thus providing a knowledge base for treatment providers. This included exploring the definitions of self-concept, and its impact throughout the life span, examining the role significant others play in its development, exploring the relationship of traditional sex-role identification to self-concept, and critiquing five available tests and measures of self-concept within this age frame.

It is apparent from the research that there is not a "universally" accepted definition of self-concept. There appears to be an intertwining of other self-prefix terms, such as self-esteem, self-acceptance, and self-ideation within the meaning of self-concept. For purposes of this research, self-concept was defined as a composite view of one's self formed through one's experience with one's environment, particularly influenced by significant others. (Calboun and Morse, 1977).

From the review of the research, it appears that the self-concept influences one throughout the life span. Mills (1984) indicates that the self-concept may be an important 
measurement of a child's readiness for scholastic work. It may be, as well, a potential indicator of future success in the classroom (Bruneau, 1984; White, 1969).

The role of the self-concept's influence is not limited to academic achievement. Overall positive feelings concerning one's self tend to promote positive accomplishments throughout the lifespan. Combs and Snyggs (1959) describe the self-concept as a "cornerstone" for all other thoughts and behaviors. The impact upon career choice has been documented (Super, 1969; Wise, 1976), as well as the influence upon a successful attainment of an intimate relationship (Newman, and Newnan, 1979). The quality of one's feeling of productivity in middle adulthood, as well as general life satisfaction in later years, appear also to be affected by one's self-concept, the extent to which is unknown.

Significant others appear to play a primary role in the development of one's ideations of the world and particularly of one's self. Though life is not over at three, concepts concerning self and the world have been formed (Butler, 1969). Combs and Snyggs (1959) and Kohut (1971) speak of the child as learning about self, not just from individual exploration, but through the mirror of self represented by the actions of significant others. Burns (1979) describes the logic for the impact of significant others in terms of the infant's total dependency, both physically and emotionally. 
It is these initial encounters with one's world (Erickson, 1963) that seem to set the stage for future expectations concerning life in general. At this point the infant may begin to perceive self as an asset or deficit based upon the input of individuals who make up their immediate world. This self-portrait continues to be redefined and adjusted through reinforcement in the early early jears.

The review of the literature on traditional sex-role identification and sex-role stereotyping indicates potential impact upon the child's developing concept of self. (Mussen, 1969; Yamamoto, 1972; and Burger, 1980). Burns states that (1979, p. 214): "Differential identification with parents and parent surrogate models, acquisitions of sex-typed skills and sex-role congruent experiences are each influential in determining the degree to which an individual labels himself as masculine or feminine." It appears that relevant behavior from a same-sex parent who is nurturing and rewarding, and an opposite-sexed parent, who supports and rewards the same sex identification, while also being nurturing, encourages traditional sex-role identification.

The basic understanding of sex-role identification occurs early. Elrod and Crase (1980) indicate at age two a child is aware of some of the current sex-role stereotypes. Again, significant others can be seen as playing a major role in one's belief about the sexes. It 
appears that one of the stereotypes, still in existence, is that of greater valuing of males over females. The implications are twofold: males appear to have a more positive self-concept than females, and there is a trend towards females becoming more masculine.

Five measures of self-concept were critiqued. All were found to be wanting, though one, the Piers Pre-school Pictorial Self-Concept Scale was thought by Jensen (1983) to have promise as a valid and reliable measure. Wylie (1961, 1979) and Shavelson, Hubner, and Stanton (1976) point out that this may be due, in part, to the lack of a clear definition of self-concept. They also indicate the current lack of adequate validation and interpretations of self-concept measures in use, as well as a lack of empirical data on the equivalence of many measures. A subsequent lack is that of adequate tests specifically designed for use with this age population.

\section{Implications for treatment providers}

1. A universally accepted definition of self-concept does not exist. Most researchers reviewed acknowledge the existence of "something" which they call self-concept. However, the inability of these researchers to agree upon a definition may logically require skepticism about its existence. If treatment providers choose to acknowledge self-concept enhancement as a goal, 
they should recognize the hazards of selecting their own definition, and the need to establish and clarify a working definition for themselves and others who may be involved in the treatment process.

2. The review of the literature indicates there is input from significant others on the child's developing view of self. The significance of this input is unclear. Considering this potential influence, treatment providers should develop programs to address stage appropriate needs. Simply stated, there would be an emphasis upon: (a) prenatal concerns; (b) physiological needs of the newborn and awareness of separation issues; (c) the individuation needs of the toddler; and (d) the continued mastery of skills of the four and five year old.

3. The review of the literature involves addressing the development of traditional sex-role identification and sex-role stereotyping. Though there is controversy related to the definition and pervasiveness of self-concept, the impact of significant others upon sex-role identification and stereotjping is more conclusive. Therefore, based on this review, treatment providers should work with both the significant others and the child in broadening perspectives of maleness and 
femaleness.

4. There is an apparent lack of adequate tests and measures of the roung child's self-concept. The reviewed measures should not be used as independent assessment tools. They may be utilized as projective techniques assisting the treatment provider in identifying areas of concerm for the child.

5. Individuals involved in self-concept research which focuses on intervention strategies to enhance self-concept need to work towards adequately defining self-concept and assessing the impact of interventions on the development of the child. Every attempt should be made to report these findings so that others may benefit from this information as they design and refine interventions. Finally, as eloquently stated by Maria Montessori:

We know how to find pearls in the shells of oysters, gold in the mountains and coal in the bowels of the earth, but we are unaware of the spiritual gems, the creative nebulae, that the child hides in himself when he enters this world to renew mankind. (1967, p. 9)

Perhaps information leading to the development of a positive self-concept is a beginning for bringing into awareness the "creative nebulae" found within the child. 
Baldwin, J. M. (1889). Handbook of psycholog: Senses and intellect. NY: Henry Holt.

Bell, N. J., Menke, P., and Lanke, I. (1980). Teachers' definitions of self-esteem when rating pre-school children. Perceptual and Motor Skills, 51, .292.

Benninga, J. (1980). Integration of self-concept and moral judgment: Two studies. The Journal of Genetic Psychology, 136, 25-36.

Berzins, J., Welling, M. A. and Welter, R. E. (1978). A new measure of psychological androgyny based on the personality research form. Joumal of Consulting and Clinical Psychology, 46, $126-138$.

Block, J. H. (1973). Conception of sex-role. American Psychologist, 49(6), 511-523.

Branden, N. (1969). The psychology of self-esteem. IA: Nash Publishing Co.

Briggs, D. C. (1975). Your child's self-esteem. Garden City, NY: Doubleday and Company, Inc.

Broussard, E. R. and Hartner, M.S. (1970). Maternal perception of the neonate as related to development. Child Psychiatry and Human Development, 1(1), 16-25.

Bruneau, 0. (1984). Comparison of behavioral characteristics and self-concepts of American Indian and caucasion pre-schoolers. Psychological Reports, $54,571-574$.

Burge, P. (1982). The relationship between sex-role identity and self-concept of pre-school children. Child Study Journal, 12(4), 249-257.

Burger, P. (1980). Parental sex-role attitudes related to self-concept and sex-role identity of pre-school children. Dissertation Abstracts Intermational, $40(11-A) 5762$.

Burns, R. (1979). The self-concept. NY: Longman Press.

Butler, A. I. (1969). The challenge of young children. Theory Into Practice, 8(3), 158-163.

Calhoun, G. and Morse, W. (1977). Self-concept and self-esteem: Another perspective. Psychology in the Schools, 14(3), 318-322. 
Cicirelli, V. G. (1974). The Purdue self-concept scale for pre-school children. Manual and inal report prepared for the office of Child Development, pursuant to Contract 50037). West Lafayette, Ind: Purdue University.

Combs, A. W., Soper, D. W. and Courson, C. C. (1963). The measurement of self-concept and self-report. Educational and Pstchological Measurement, 23, 493-500.

Combs, A. W. and Snjggs, $D_{\text {. }}(1959)$. Individual behavior: A
perceptual approach to behavior.

Cooley, C. (1956). Human nature and the social order. NY: The Free Press.

Cooper, J., Holman, J., and Braithwait, V. (1983). Self-esteen and family cohesion: The child's perspective and adjustment. Journal of Marriage and the Family, 6, $153-159$.

Coopersmith, S. (1967). The antecedents of self-esteem. San Francisco: Freeman Press.

Damon, W. and Hart, D. (1982). The development of self-understanding from infancy through adolescence. Child Devolopment, 53, 841-864.

Davidson, H., and Lang, G. (1960). Children's perceptions of their teachers' feelings toward them related to self perception, school achievement, and behavior. Journal of Experimental Education, 29, 107-118.

Dobson, J. (1979). Hide or seek. Old Tappan, N. J.: Fleming H. ReveII Co.

Eaton, W. O. (1983). Gender understanding and sex-role stereotyping in pre-schoolers: Inplications for care givers. Child Care Quarterly, 12(1), 28-35.

Eaton, C. W., and Von Bargen, D. (1981). Asynchronous development of gender understanding in pre-school children. Child Development, 52, 1020-1027.

Ellsworth, S. G. (1967). Building the child's self-concept. Todar's Education, 61(2), 54-56.

Elrod, M. M. and Crase, S. J. (1980). Sex differences in self-esteem and parental behavior. Psychological Reports, 46, 719-727.

Erickson, E. (1963). Childhood and society. NY: W. W. Norton and Company Inc.

Ferguson, I. (1970). Personality Development. Belmont, CA: 
Brooks Cole Publishing Co.

Gergen, R. J. (1971). The concept of self. NY: Holt, Rinehart and Winston.

Ginsberg, H. J. and Miller, S. M. (1982). Sex differences in children's risk taking behaviors. Child Development. $53(2), 426-434$.

Hall, J. A. and Halberstadt, A. G. (1980). Masculinity and femininity in children: Development of the children's personal attributes questionnaire. Developmental Psychologr, 16(4), 270-280.

Henderson, D., and Abrams, P. (1983). A comparison of selected diminsions of the self-concept and three self-concept tests for pre-school children. Early Child Development and Care, 13, 1-16.

Hurlock, E. B. (1968). Developmental psychology. (3rd ed.). NY: McGraw-Hill.

James, W. (1890). Principles of psychology. NY: Holt Press.

Jensen, M. (1983). Self-concept and its relation to age, family structure, and gender in Head Start children. The Journal of Psychology, 113, 89-94.

Kagan, J. (1968). The child: His struggle for identity. Saturday Review of Iiterature, $87,80-82$.

Kagan, J. (1984). The nature of the child. NY: Basic Books, Inc.

Kohut, H. (1971). The analysis of the self. NY:

International Universities Press.

Kuhn, D., Nash, S. C., and Brucken, I. (1978). Sexrole concepts of two and three year olds. Child Development, 49, 445-451.

Landry, R., Schilson, E., and Pardew, E. M. (1974). Self-concept enhancement in a pre-school program. The Journal of Experimental Education, 42(4), 423-427.

Iewis, M. (1979). The self as a developmental concept. Human Development, 22, 416-419.

Lowenthal, M. F., and Haven G. T. (1975). Four stages of life. San Francisco: Jossey-Boss.

Maccoby, E., and Jacklin, C. (1974). The psychology of sex differences. Stanford, CA: Stanford University Press. 
MacDonald, R. R. (1973). Paratoxic distortion and perceived parenting. Journal of Genetic Psychology, 123, 337-343.

McCandles, B. R., and Evans, E. D. (1973). Children and youth, Psychosocial development. Hinsdale, IL: The Dryden Press.

Mills, B. (1984). An investigation of the relationship of the self-concept and young children's readiness for school. Early Child Development and Care, 14, 177-188.

Montessori, M. (1967). The absorbant mind. NY: Holt, Rinhart, and Winston.

Mussen, P. H. (1969). Early sex-role development. In D. D. Goslin (Ed.). Handbook os socialization theory and research. Chicago: Rand-McNally.

Newman, B., and Newman P. (1979). Development through life. Honcewood, II: The Dorsey Press.

Peairs, I., and Peairs, R. (1974). What every child needs. NY: Harper and Row Publishers.

Piers, E. V. and Harris, D. B. (1964). Age and other correlates of self-concept in children. Journal of Educational Psychology, 55, 91-94.

Raimy, V. (1971). The self-concept as a factor in counseling and personality organization. Chicago: The Obio Libraries.

Raschke, H. J. and Raschke, V. J. (1979). Family conflict and children's self-concepts, a comparison of intact and single-parent families. Journal of Marriage and the Family, 41, 367-374.

Robeck, M. (1978). Infants and children. NY: McGraw-Hill Book Co.

Rogers, C. R. (1951). Client centered therapy. Boston: Houghton Mifflin.

Rosenberg, M. (1963). Parental interest and children's self-conceptions. Sociometry, 26, 35-49.

Rosenberg, M. (1979). Conceiving the self. NY: Basic.

Rosenthal, R., and Jacobson, I. (1968). Pygmalion in the classroom: Teacher expectation and pupil's intellectual development. NY: Holt, kinehart, and Winston.

Samuels, D., and Griffore, H. (1978). The relationship 
between matermal anxiety and self-esteem of pre-school aged children. Child Study Journal, 8(2), 93-99.

Sandler, J., and Joffe, W. (1968). The role of learning in psychotherapy. London: J \& A. Churchilil, Ltd.

Schwartz, M. (1982). Effects of maternal sex-role attitudes on certain aspects of pre-schooler's behavior.

Dissertation Abstracts International, $43(1-\mathrm{A}), 123$.

Sears, P. S., and Sherman, V. S. (1964). In pursuit of self-esteem. Belmont, $\mathrm{CA}$ : Wadsworth Fublishing Co.

Sears, R. E. (1970). Relation of early socialization experiences to self-concepts and gender role in middle children. Child Development, 41, 267-289.

Secourd, P. F., and Jourard, S. M. (1983). The appraisal of body-cathexis: Body-cathexis and the self. Journal of Consulting Psychology, 17(3), 343-347.

Shavelson, R. J., Hubner, J. J., and Stanton, G. C. (1976). Self-concept: Validation of construct interpretations. Review of Educational Research, 46, 407-441.

Slaby, R. G., Frey, K. S. (1975). Development of gender constancy and selective attention to same-sex models. Child Development. 46, 849-856.

Soule, J., Drummond, R., and McIntire, W. (1981). Dimensions of self-concept for children in kindergarten and grades 1 and 2. Psychological Reports, 48. 83-88.

Stringer, I. A. (1971). The sense of self, a guide to how we mature. Philadelphia: Temple University Press.

Super, D. E. (1969). Vocational development theory: Persons, positions, and process. Counseling Psychologist, 1, 2-9.

Thomas, W. (1969). The assessment of self-concept values among 4- to 9-year old children. The Thomas self-concept values test. Detroit: Educational Services Company.

Thompson, S. K. (1975). Gender labels and early sex-role development. Child Development, $46,849-856$.

White, W. F. (1969). Psychosocial principles applied to the classroom. NY: McGraw-Hill.

White, W. F. and Human, S. (1976). Relationship of 
self-concepts of three-, four-, and five year old children with mother, father, and teacher precepts. The Joumal of Psychology, 92, 191-194.

Williams, R. I. , and Cole, S. (1968). Self-concept and school adjustment. Personnel and Guidance Journal, $46,478-481$.

Wise, R., Charner, I., and Randour, M. I. (1976). A conceptual framework for career awareness and career decision-making. The Counseling Psychologist, 47-53.

Wylie, R. (1961, 1979). The self-concept. Lincoln: University Press.

Yamamoto, K. (1972). The child and his image. Boston: Houghton Mifflin Co.

Yeatts, P. and Bently, E. S. (1968). The development of a nonverbal measure to assess the self-concept of young and low-verbal children. Paper presented at American Educational Research Association Meeting, New York.

Zalk, S. R., and Katz, P. A. (1978). Gender attitudes in children. Sex Roles, 4, 349-357. 